\title{
Empowerment Of Women Households Group Of Poor Families To Increase Income Through Training To Make Dimsum In Padang Bulan Village, Medan
}

\author{
Onan M Siregar ${ }^{1}$, Husni Thamrin, ${ }^{1}$ Hatta Ridho ${ }^{1}$, Fajar Utama Ritonga ${ }^{1}$, Adil Arifin ${ }^{1}$ \\ ${ }^{1}$ Faculty of Social and Political Sciences, University of North Sumatra, Medan \\ Email: *onan@usu.ac.id
}

\begin{abstract}
Community service activities are carried out through training on how to make dim sum which is carried out for mothers from poor family groups located in Padang Bulan Village, Medan City. Based on data and observations that mothers from poor groups who do not have a job other than taking care of their family, the purpose of this service is to provide training to mothers from poor family groups to make decent dim sum for sale so that they can increase family income. The method in this activity is carried out by socializing and giving lectures to training participants as well as doing hands-on practice how to make dough for dim sum ingredients and form dim sum properly to sell to consumers. Through the dim sum making training activities, mothers from poor family groups will become skilled and have the expertise to make and sell dim sum to the community which in turn will increase family income.
\end{abstract}

Keywords : Community empowerment, Dimsum, Padang Bulan Medan Village, Poor family groups

\begin{abstract}
Abstrak
Kegiatan pengabdian kepada masyarakat dilakukan melalui pelatihan cara membuat dimsum yang dilaksanakan kepada ibu-ibu dari kelompok keluarga miskin bertempat di Kelurahan Padang Bulan Kota Medan. Berdasarkan data dan pengamatan bahwa ibu-ibu dari kelompok miskin yang tidak memiliki pekerjaan selain mengurus keluarga saja.Tujuan dari pengabdian ini adalah memberikan pelatihan kepada ibu-ibu dari kelompok keluarga miskin membuat dimsum yang layak untuk dijual sehingga dapat menambah pendapatan keluarga. Metode dalam kegiatan ini dilakukan dengan cara sosialisasi dan ceramah kepada peserta pelatihan serta melakukan praktik langsung bagaimana membuat adonan bahanbahan dimsum dan membentuk dimsum dengan baik untuk layak jual kepada konsumen. Melalui kegiatan pelatihan pembuatan dimsum, ibu-ibu dari kelompok keluarga miskin akan menjadi terampil dan memiliki keahlian untuk membuat dan menjual dimsum kepada masyarakat yang pada ahirnya akan menambah pendapatan keluarga.
\end{abstract}

Kata Kunci : Pemberdayaan masyarakat, Dimsum, Kelurahan Padang Bulan Medan, Kelompok keluarga miskin

\section{PENDAHULUAN (INTRODUCTION)}

Ditengah situasi pandemi Covid-19 yang melanda hampir seluruh wilayah menyebabkan situasi semakin sulit, terutama perekonomian. Banyak para ahli mengatakan situasi ini akan menyebabkan bertambahnya orang miskin di Indonesia karena banyaknya orang yang kehilangan pekerjaan. Menteri Keuangan RI menyampaikan Pandemi, wabah Covid-19 berdampak pada pembangunan yaitu berbagai aspek, termasuk bidang sosial. Pandemi mengakibatkan akan ada tambahan 1,1 juta masyarakat miskin. Selain itu Sri Mulyani menyampaikan jika Pandemi terus berlanjut orang miskin di Indonesia dapat mencapai 3,78 juta orang. Dampak Covid-19 mengakibatkan bertambahnya 2,9 juta pengangguran baru, bahkan bisa mencapai 5,2 juta.

Berdasarkan data BPS tahun 2019 warga miskin di Kota Medan tercatat 463.000 hampir 20 persen dari jumlah penduduk kota Medan yang berjumlah 2,6 juta jiwa, sementara yang mendapat bantuan dari pemerintah pusat melalui kementerian sosial hanya 65.342. Melihat kondisi keluarga miskin pada umumnya seluruh sumber daya manusia disiapkan untuk memperoleh pendapatan sebagai upaya untuk membantu memenuhi kebutuhan sehari-hari. Oleh sebab itu dalam keluarga miskin, ibu-ibu akan berusaha untuk bisa melakukan berbagai pekerjaan, terutama kerja yang tidak membutuhkan ketrampilan atau keahlian tertentu, mudah untuk dimasuki dan tidak membutuhkan modal yang besar sebagaimana layaknya memulai usaha. Ibuibu pada rumah tangga miskin, rata-rata memiliki tingkat pendidikan yang relatif rendah karena kondisi 
Onan M Siregar, et al Empowerment Of Women Households Group Of Poor Families To Increase Income Through Training To Make Dimsum In Padang Bulan Village, Medan

ekonomi yang melatarbelakanginya. Salah satu cara yang bisa dilakukan oleh ibu rumah tangga dari keluarga miskin adalah membuat makanan yang diminati oleh orang banyak seperti dimsum. Untuk itu diperlukan pengetahuan yang cukup dan ketrampilan dalam membuat olahan makanan dimsum yang enak dan layak dijual.

Dimsum terbuat dari kulit pangsit berisi aneka makanan laut, seperti udang dan kepiting. Agar makin mendapat tempat di lidah masyarakat, kini isian dimsum kian beragam, seiring makin banyak pelaku usaha yang menjalankan bisnis ini. Sebut saja beberapa inovasi isian dimsum yang mulai disukai, seperti telur puyuh, jamur, sosis, dan banyak lagi. Lantaran ceruk pasar kudapan asal China ini masih cukup besar, tidak sedikit pelaku usaha mengembangkan bisnisnya karena besarnya permintaan pasar. Makanan dimsum sangat disukai oleh hampir semua kalangan masyarakat terutama generasi milenial yang senang mencoba hal-hal baru. Awalnya dimsum dianggap sebagai makanan mahal yang hanya dikonsumsi oleh orang berduit saja. Jika mau mengkonsumsi dimsum maka harus ke restoran besar dan mahal sehingga dimsum menjadi makanan kalangan kelas atas. Seiring dengan berkembangnya cara pembuatan dimsum maka dimsum yang dulu dikonsumsi saat minum teh, sekarang telah mengalami perubahan. Selain itu restoran-restoran telah menyediakan menu aneka dimsum dengan berbagai macam penyajian.

Orang yang menyukai dimsum semakin banyak, sehingga muncul kreativitas untuk membuat dimsum siap saji. Hal ini membuat dimsum menjadi makanan yang diminati dan dimsum siap saji dapat dibeli di berbagai supermarket besar. Berbagai acara pesta tidak ketinggalan menyediakan makanan yang berasal dari negeri Cina sebagai hidangan favorit yang diminati oleh tamu-tamu dan paling cepat habis dibandingkan makanan lainnya semakin terkenalnya makanan dimsum ini membuat berbagai kalangan berusaha untuk membuat dimsum dengan berbagai cara agar harganya semakin terjangkau oleh seluruh lapisan masyarakat. Saat ini sudah banyak kita temui dimsum dengan harga yang bervariasi. Mulai dari restoran kalangan atas warung kaki lima menyediakan dimsum. Dengan semakin terjangkaunya harga dimsum maka tidak lagi diperlukan investasi besar, membangun restoran besar dan mewah. Melalui sedikit investasi kita bisa menjual dimsum dengan harga terjangkau dan mendapatkan keuntungan yang cukup besar.

Berdasarkan apa diuraikan diatas, maka pelatihan pembuatan dimsum menjadi pilihan tim pengabdian yang akan diberikan kepada ibu-ibu rumah tangga dari kelompok keluarga miskin yang membutuhkan tambahan pendapatan ditengah situasi yang sulit ini. Dari paparan tersebut diatas, maka dapat dipetakan permasalahan pada Mitra rendahnya kesadaran masyarakat Kelurahan Padang Bulan akan pentingnya melakukan kegiatan wirausaha terutama ibu-ibu rumah tangga dari kelompok keluarga miskin untuk diberikan pelatihan yang bisa memberikan kesempatan untuk menambah pendapatan.

\section{METODE PELAKSANAAN}

Kegiatan pengabdian masyarakat ini menggunakan metode:

1. Ceramah dan sosialisasi untuk menyampaikan pengetahuan secara umum tentang berbagai macam jenisjenis dan kreasi produk dimsum, yaitu meliputi bahan dan alat yang digunakan, kegunaan alat dan bahan yang digunakan serta proses pembuatan hingga menjadi dimsum siap saji.

2. Praktik langsung kepada seluruh peserta pelatihan bagaimana mengolah dan membentuk dimsum dengan baik dan benar serta memberikan petunjuk terhadap hal-hal yang harus dihindari dalam mengolah atau membentuk dimsum.

\section{HASIL DAN PEMBAHASAN}

Hasil dari pengabdian masyarakat di Kelurahan Padang Bulan memfokuskan pada keterampilan peserta pemberdayaan untuk mahir membuat dimsum yang menarik dan memasarkannya kepada masyarakat yang dimulai dari tahapan persiapan dan hasil yang dicapai. Pada pelaksanaan pengabdian dilakukan dengan cara penyuluhan, demonstrasi pemilihan bahan-bahan yang digunakan dan praktik langsung pembuatan dimsum.

Persiapan dilakukan oleh Tim Pengabdian bersama-sama dengan mitra. Persiapan dilakukan untuk memperoleh kesepakatan antara Tim Pengabdian dan mitra, meliputi: jadwal kegiatan dan tempat kegiatan. 
Onan M Siregar, et al Empowerment Of Women Households Group Of Poor Families To Increase Income Through Training To Make Dimsum In Padang Bulan Village, Medan

Pada tahap persiapan disepakati tentang waktu dan tempat pelaksanaan penyuluhan maupun waktu dan tempat pelaksanaan pelatihan pembuatan dimsum yang dilakukan di kantor Kelurahan Padang Bulan Kota Medan bekerja sama dengan PKK Kelurahan pelaksanaan pengabdian masyarakat dilakukan melalui penyuluhan, demonstrasi yang dimulai dari pengenalan dan pemilihan bahan-bahan yang digunakan, proses pengolahan bahan-bahan, membentuk model dimsum.

Penyuluhan bertujuan untuk memberikan motivasi kepada mitra agar memiliki semangat berwirausaha dan memiliki ketrampilan untuk membuat dimsum yang layak jual. Penyuluhan yang diberikan terdiri dari penyuluhan kewirausahaan, penyuluhan pemberdayaan ibu rumah tangga, dan penyuluhan pengelolaan usaha dimsum. Pada demonstrasi pemilihan dan pengolahan bahan-bahan dimsum, pelatih memperlihatkan bahanbahan yang digunakan dan menjelaskan cara pemilihan bahan yang baik untuk membuat dimsum. Kemudian pelatih mendemonstrasikan cara pengolahan kepada peserta. Pelatih menjelaskan prosedur yang akan dilakukan dan memperlihatkan alat-alat yang digunakan sebelum memperlihatkan bagaimana membuat dimsum. Hasil kegiatan Program Pengabdian Masyarakat adalah identifikasi permasalahan pada kurangnya kesadaran kaum ibu dari kelompok keluarga miskin untuk berwirausaha dan rendahnya pengetahuan membuat dimsum.

Hasil pelaksanaan kegiatan pengabdian pada masyarakat melalui pemberdayaan ibu-ibu kelompok keluarga miskin untuk menambah pendapatan melalui pelatihan pembuatan dimsum di Kelurahan Padang Bulan adalah ibu-ibu rumah tangga dari kelompok miskin muncul minatnya untuk melakukan usaha. Melalui sosialisasi diberikan pemahaman dan penjelasan bahwa ibu rumah tangga bisa membantu mencari tambahan uang dengan melakukan usaha. Pada sosialisasi diberikan contoh-contoh ibu-ibu yang sebelumnya tidak memiliki usaha ketika mau berusaha maka dapat berhasil menjalankan usaha dengan baik dan menghasilkan keuntungan yang dapat membantu perekonomian keluarga

Dalam sosialisasi disampaikan bahwa membuat dimsum yang layak jual tidak sulit. Tidak harus mengikuti kursus berhari-hari dengan biaya yang mahal. Selain itu akan muncul pemahaman bahwa potensi pasar penjualan dimsun besar karena sangat diminati oleh akan-anak muda yang dikenal sebagai generasi milenial.

\section{KESIMPULAN}

\subsection{Kesimpulan}

Kegiatan program pengabdian masyarakat ini diharapkan mampu memberikan manfaat pada ibu-ibu kelompok keluarga miskin untuk menambah pendapatan melalui kegiatan pelatihan membuat dimsum di Kelurahan Padang Bulan Medan. Selanjutnya mitra melakukan pembinaan kepada ibu rumah tangga khususnya kelompok keluarga miskin untuk menambah pendapatan melalui keterampilan membuat dimsum.

\subsection{Saran}

1. Pihak Kelurahan melalui PKK terus melakukan pembinaan dan mendorong masyarakat khususnya kelompok keluarga miskin di Kelurahan Padang Bulan untuk memiliki keterampilan membuat dan memasarkan dimsum yang layak jual kepada masyarakat sehingga dapat menambah pendapatan keluarga.

2. PKK membentuk kelompok kewirausahaan dari keluarga miskin untuk melakukan pembinaan bagi ibu rumah tangga yang serius untuk menjalankan usaha dimsum secara online dengan memberikan bantuan modal atau pinjaman dengan bunga rendah.

\section{UCAPAN TERIMA KASIH}

Artikel ini merupakan salah satu hasil dari Program Pengabdian kepada Masyarakat yang Dibiayai oleh dana NON PNBP Universitas Sumatera Utara Sesuai dengan Surat Perjanjian Penugasan Pelaksanaan Pengabdian kepada Masyarakat Program Dosen Mengabdi Tahun Anggaran 2020. Oleh karena itu, diucapkan terima kasih 
Onan M Siregar, et al Empowerment Of Women Households Group Of Poor Families To Increase Income Through Training To Make Dimsum In Padang Bulan Village, Medan

kepada Rektor Universitas Sumatera Utara atas dukungan dana dan fasilitas yang diberikan. Terima kasih juga kepada Mitra pada kegiatan pengabdian ini.

\section{DAFTAR PUSTAKA}

Alifiana, Mia Ajeng, 2018, Peningkatan Pendapatan Rumah Tangga Melalui Pemberdayaan Ibu-Ibu PKK, Journal Dedicators Cummunity, Vol2, No. 2.

Anwar, Yuyun. 2012, Mengeruk Untung Usaha Dimsum Kaki Lima: Kiat Sukses Berbisnis Dimsum Dengan Modal Tipis Era Krisis. http://www.yuyunanwar.com/2012/01/mengeruk-untung-usaha-dim-sum-kakilima.html

Arvianti, Eri Yusnita, Suroto, Karunia Setyowati, Situmeang, Touruman, Pemberdayaan Wanita Pada Dia Kelompok Ibu Rumah Tangga Bhakti Luhur dan Sekarwangi Dalam Membantu Peningkatan Pendapatan Keluarga, Jurnal Akses Pengabdian Indonesia Vop 1 No. 1: 1-7, 2016

Fitria, Eva, 2019, Peran Aktif Wanita Dalam Peningkatan Pendapatan Rumah Tangga Miskin: Studi Kasus Pada Wanita Buruh Perkebunan PT Asian Agri di Dusun Pulau Intan, Ecobisma (Jurnal Ekonomi, Bisnis dan Manajemen), Vol 6, No. 2

Mbakevi. 2011. Sejarah dan Asal Mula Masakan Dimsum yang Lezat. http://mbakevi.wordpress.com/2011/10/06/151/.

Priyanto, Sony Heru. "Mengembangkan Pendidikan Kewirausahaan di Masyarakat". 01 Oktober 2015.

Purwanto, Didik . 17 November 2015. " Tujuan dan Manfaat Kewirausahaan"

Suryana. 2006. "Kewirausahaan-Pedoman Praktis :Kiatdan Proses Menuju Sukses". Bandung :Salemba Empat

Wibowo, NT. 2012. Macam dan Fungsi Bahan-bahan pada Adonan Dimsum. Online. http://jendelakokojava.blogspot.com/2012/09/macam-dan-fungsi-bahan-bahan-pada-adonan.html

Winata, Mary."100 Resep Dimsum Populer Untuk Usaha Boga", Gramedia, 2013 "Resep Dimsum Paling Gampang, Gramedia, 2013 